http://jmscr.igmpublication.org/home/

ISSN (e)-2347-176x ISSN (p) 2455-0450

crossref DOI: https://dx.doi.org/10.18535/jmscr/v7i10.117

\title{
An Experience in the Neck Dissection for Oral Squamous Cell Carcinoma
}

\author{
Authors
}

\author{
R.Suresh Kumar, R. Ramesh, K. Ravichandran, R. Jayaraman \\ Department of General Surgery, Rajah Muthiah Medical College and Hospital
}

\begin{abstract}
Introduction: The single most important factor affecting the prognosis for squamous cell carcinoma of the oral cavity, is the status of the cervical lymph nodes. Metastasis to the regional lymph nodes reduces the 5year survival rate by 50\% compared with that of patients with early stage disease. Therefore, management of the cervical lymph nodes is an important component in the overall treatment plan for patients with carcinomas of the oral cavity.

Materials and Methods: During the period of 2017 to 2019 data were collected from patients who attended the General surgical wards of Rajah Muthiah Medical College and Hospital, Chidambaram with suspected metastatic nodes with known primary. In patients who presented with known primary and a metastatic node, the primary was thoroughly examined at its size, shape, gross appearance, consistency were all noted. Then the neck nodes were examined and its site, size, shape, consistency, number, mobility, fixity to skin and deeper structures like carotid artery, muscle and cranial nerve involvement. A lymph node was taken as significant if it was in the drainage area of the primary, hard and above $1 \mathrm{~cm}$ in size.

Results: Out of 30 patients included in the study, Male patients were 21 and female patients were 9, which accounts to around $70 \%$ and $30 \%$ respectively. The Male and female ratio was found as 2.3:1.Maximum age incidence was found as 46-65 years of age. The higher incidence of oral cavity cancers should be attributed to tobacco chewing and alcohol intake.

The commonest site of nodal metastasis was in the upper deep cervical group in $42 \%$ (Level II and III) followed by submandibular group in 27\% (Level I), lower deep cervical group in 25\% (Level IV) and posterior triangle group in $6 \%$ (Level V)

Out of 30 patients with known primary with neck secondaries, 6 Patients were in N1 (22\%), 14 patients in N2 (46\%) and 10 patients in N3 (33\%).

Conclusion: Out of 30 patients included in the study, most common age group requiring Neck dissection is around 46 years and 65 years. Definitive male preponderance was noted. All patients who underwent Radical or Modified Radical Neck dissection for Squamous Cell Carcinoma was treated postoperatively with Radiotherapy. Shoulder Dysfunction was the most common complication of Radical Neck Dissection. No recurrence was found in the mean follow up period of one year.

Keywords: Oral cancers, Oral malignancy, neck dissection, modified radical neck dissection, radical neck dissection.
\end{abstract}

\section{Introduction}

Head and neck malignancies include malignant tumours of the upper aero digestive tract, paranasal sinuses and the major and minor salivary glands. In addition, tumours of the skin, soft tissue, bone and neurovascular structures in the head and neck and tumours of parapharyngeal space and thyroid and parathyroid glands are 
considered as head and neck malignancies. The most common site of primary in head and neck was oral cavity. The single most important factor affecting the prognosis for squamous cell carcinoma of the oral cavity, is the status of the cervical lymph nodes.

Metastasis to the regional lymph nodes reduces the 5yearsurvival rate by $50 \%$ compared with that of patients with early stage disease. Therefore, management of the cervical lymph nodes is an important component in the overall treatment plan for patients with carcinomas of the oral cavity.

The aim of the study is to study the various types of head and neck malignancies with special reference to Radical and Modified Radical neck dissection as a modality in the management regimen in the department of surgery at Rajah Muthiah Medical College and Hospital, Chidambaram.

\section{Methods and Materials}

This is anprospective study conducted in Department of General surgery in Rajah Muthiah Medical College, between the period of November 2017 to October 2019 and patients are selected on purposive sampling method based on the inclusion and exclusion criteria were included in the study. Patients included in the study of after obtaining consent and detailed history, general physical examination and neurological examination. Routine investigations such as complete hemogram, TLC, DLC, ESR, FBS, RFT and other investigations such as ECG, Chest X-ray etc are done. Among these patients, Nodal status was assessed using FNAC or Wedge Biopsy, CTNECK and USG-Neck. Intraoperative findings like Nodal involvement, Amount of bleeding and the complications following the surgery are recorded.

\section{Results and Discussion}

The findings of the study are:

The most common age group involved in Oral cavity malignancy ranges between 46 to 65 years of age.Among 30 patients who presented to the surgical clinics with known primaries with neck secondaries, there were 21 male patients accounting for $70 \%$ and 9 female patients accounting for $30 \%$. The male female ratio was 2.3:1. This is in accordance with the reports of journal of craniomaxillo facial surgery. Out of 30 patients with known primary, Out of 30 patients with known primary, 6 patients $(20 \%)$ were in stage $\mathrm{T} 1$ and $\mathrm{T} 2,20$ patients $(67 \%)$ at stage $\mathrm{T} 3$ and 4 patients $(13 \%)$ at stage T4.The commonest site of nodal metastasis was in the upper deep cervical group in $42 \%$ (Level II and III) followed by submandibular group in $27 \%$ (Level I), lower deep cervical group in 25\%(Level IV) and posterior triangle group in 6\% (Level V).

Table 1:- Age Distribution

\begin{tabular}{|l|l|l|}
\hline Sex & Number of patients & Percentage \\
\hline Male & 21 & $70 \%$ \\
\hline Female & 9 & $30 \%$ \\
\hline
\end{tabular}

Table 2:- Age Distribution

\begin{tabular}{|l|c|c|c|}
\hline \multirow{2}{*}{ Sex } & \multicolumn{3}{|c|}{ Age in years } \\
\cline { 2 - 4 } & $\mathbf{2 5 - 4 5}$ years & $\mathbf{4 6 - 6 5}$ years & $\mathbf{6 6 - 8 5}$ years \\
\hline Male & 3 & 20 & 2 \\
\hline Female & 1 & 2 & 2 \\
\hline
\end{tabular}

\section{T Stage of the Tumour}

Out of 30 patients with known primary, 6 patients (20\%) were in stage T1 and T2, 20 patients (67\%) at stage T3 and 4 patients (13\%) at stage T4.

\section{Site of Nodal Metastasis}

The commonest site of nodal metastasis was in the upper deep cervical group in $42 \%$ (Level II and III) followed by submandibular group in $27 \%$ (Level I), lower deep cervical group in $25 \%$ (Level IV) and posterior triangle group in $6 \%$ (Level V).

\section{Follow Up}

Monthly follow up was made in the first year after surgery and bimonthly follow up in the second year.

\section{Conclusion}

In our study we concluded that:

The commonest presenting age of the patient was between 46 years and 65 years. 
- A definite male preponderance was noted.

- The combination of Radical neck dissection or Modified radical neck dissection with pre or post operative radiotherapy given for patients with squamous cell carcinoma.

- Shoulder dysfunction was the commonest complication of Radical neck dissection.

- No recurrence was found in a mean follow up period of 1 year.

\section{References}

1. Assessment of risk factors for oral squamous cell carcinoma in Chidambaram, Southern India: a case-control study Rajamanickam Subapriya, Annamalai Thangavelu, Bommayasamy Mathavan, Chinnamanoor R Ramachandran, Siddavaram Nagini European Journal of Cancer Prevention 16 (3),251-256, 2007.

2. Current aspects on oral squamous cell carcinoma Anastasios K Markopoulos. The open dentistry journal 6, 126, 2012.

3. Challenges of the Oral Cancer Burden in India Ken Russell Coelho

4. Oral squamous cell carcinoma overview. Crispian Scully, Jose Bagan, Oral oncology 45 (4/5), 301-308, 2009.

5. Lymph Node Metastases in Oral Carcinoma A Correlation of Histopatliology with Survival R Barrett Noone, Hugh Bonner JR, Samuel Raymond, Arthur S Brown, William P Graham Iii, Herndon B Lehr Plastic and reconstructive surgery 53 (2), 158-166, 1974.

6. Age specific incidence rate and pathological spectrum of oral cancer in Allahabad Author: Ravi Mehrotra; Mamta Singh; D. Kumar; A. N. Pandey; R. K. Gupta; U. S. Sinha.
7. Pathologic evaluation of sentinel lymph nodes in oral squamous cell carcinoma Nirav P. Trivedi MS, MCH Hiran Kattilaparambil Ravindran MD, DNB Shanmugham Sundram MD SubramaniaIyer MS, FRCS, MCH Vikram Kekatpure MS, MCh Sundeep Durah MS Moni Abraham Kuriakose MD, BDS, FDSRCS, FFDRCS, FRCS Ed, FRCS.

8. Role of ultrasound in detection of metastatic neck nodes in patients with oral cancer P Sureshkannan, Vijayprabhu, Reena John.

9. Cervical lymph node metastasis: assessment of radiologic criteria. $\mathrm{M} \mathrm{W}$ van den Brekel, H V Stel, J A Castelijns, J JNauta, I van der Waal, J Valk, C J Meyer, G B Snow.

10. Selective Neck Dissection in the Management of the Clinically Node- Negative Neck A. SefikHosalMD Ricardo L. Carrau MD Jonas T. Johnson MD Eugene N. Myers MD. 